\title{
Students' Perspective on English Pragmatic Based Material for Students of Hotel Management Study Program
}

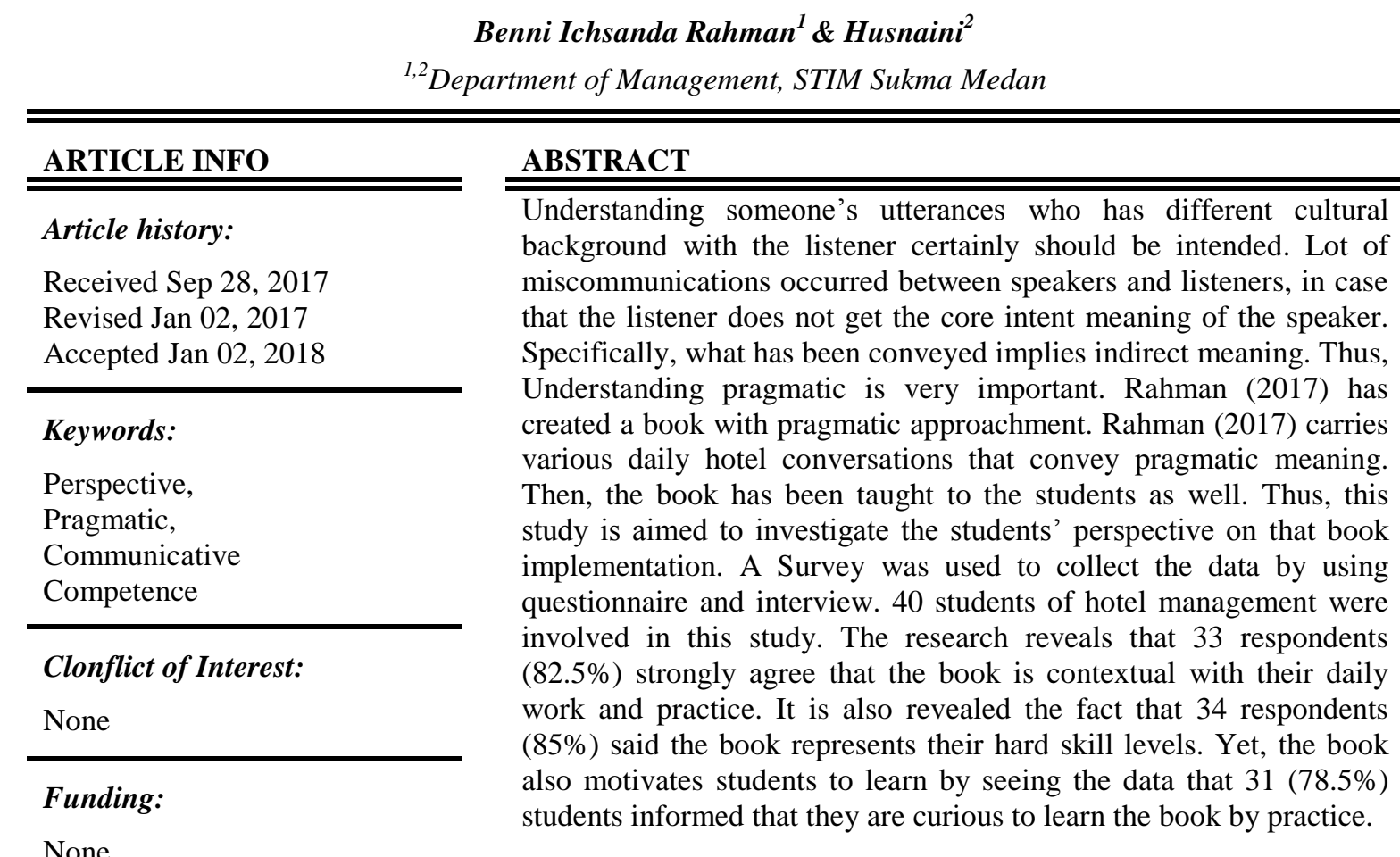

Corresponding Author: Benni Ichsanda Rahman, Sekolah Tinggi Ilmu Manajemen Sukma, Medan, 20218 North Sumatera, Indonesia Phone.+62822-7327-4623 E-mail: ichsandabenny@ gmail.com

\section{INTRODUCATION}

\subsection{Background of the Study}

As the biggest archipelago country in the world, Indonesia has much potency to be developed. One of the potency is tourism sector. Thus, to balance the potency, many education institutions take the opportunity to develop nations' human resources. Many education institutions develop programs of study that concern on tourism and hotel management development.

As consequence, the programs have to develop the human resources that match the needs. One of the units should be developed is the English competencies of the resources. This is related to the fact that the resources will meet and face the tourists from foreign countries who will visit Indonesia. Thus, English competencies are definitely needed by the "tourism sector actors".

As well as, almost all higher institutions of education implemented basic English courses, and other subjects (such as English conversations, and TOEFL-Test of English as Foreign Language) to their programs curriculum, to balance the students needs English. Related to the fact, if we observe more seriously and directly to some of the existing higher education institutions, including Sukma School of Management (Sekolah Tinggi Ilmu Manajemen Sukma), the reality found that these institutions 
have not implemented "cultural understanding" or "pragmatic understanding" to the English curriculum in particular, as well as to the curriculum of the study program in general.

Beside, pragmatic understanding is a unit that absolutely needed by communicators in studying and practicing English. According to Levinson (in Saeidi et al, 2014), pragmatic is a study of language in context. It is the relationship between the code of the utterers and the listener. Or simply defined, pragmatics is how language and its style used in communication. In addition, Kasper and Rose (in Saeidi et al, 2014) stated that pragmatics is a lesson on the use of communication in a socio-cultural context. Thus, pragmatic studies are closely related to speech acts in a social context. The ability to understand and use speech acts is known as pragmatic competence related to cultural knowledge and linguistic knowledge as well as social distance between the two people: speaker and listener.

Understanding pragmatic is very important. Understanding someone's utterances which has different cultural background with the listener certainly should be intended. Lot of miscommunications occurred between speakers and listeners, in case that the listener does not get the core intent meaning of the speaker. Specifically, what has been conveyed implies indirect meaning. The fiasco is caused by the incompetence of the listener to understand the cultural characteristics of the speaker. Vice versa, the speaker does not realize that what he commonly says in his country is not understood by listeners from other countries or other regions. In conclusion, it is strongly believed that language is the part of the culture.

Therefore, to learn a language should also be in conformity to learn the culture of the native cultures languages, especially how the implementation of language is influenced by the native cultural background. Thus, people who study a certain language but do not convey its culture, will tend to "confused and miscommunication".

To balance the need, Rahman (2018) has created a book that contains pragmatic understanding on it. He wrote an English book for university students of hotel and tourism management with pragmatic approach. The book accommodates conversations that convey "indirect meaning" between the speakers and listeners. Every chapter illustrates conversations with wide pragmatic understanding. The conversations are contextual as if they are in real hotel and tourism situations. The book is going to be taught to the students where Rahman (2018) teaches.

Thus, this research is going to investigate, whether the book is acceptable for the students or not. The research will survey the students, what their perspectives are about the book.

\subsection{Objective of the Study}

This study is aimed to know the students' perspective on Rahman's book (2017) "English Pragmatic Based Materials for Students of Hotel Management Study Program", whether the book is acceptable or not.

\section{LITERATURE REVIEW}

\subsection{Relationship between Language and Culture}

Language is strongly related with culture. Even, language is a part of culture. It was explained by Halliday (quoted by Santoso, 2007) that formation of language is bounded completely with culture, due to the fact that language is used regularly and daily which form a character.

In addition, language has representativeness (Halliday in Santoso, 2007). Language intends the function of ideas of the speakers which carry their experiences from the derived world into form of language. The smallest units of language are formed by the text that carries "register". Register is defined as a combination of the speaker and the listener (called as tenor), the topic of the conversation (field), and the way it is being delivered (mode). Those complexities are a unity that cannot be separated with culture.

\subsection{Pragmatic Mastery}

Mastering pragmatic meaning in language is meant also mastering the language use. In this term, it is called as communicative competence. According to Canale and Swain (in Bagaric \& Djigunovic, 2007), communicative competence is the knowledge and skills system synthesis which are required by people in doing communication. In communicative competence framework, language 
understanding is the individual's unconsciousness of communication tools and language application proposition. Canale and Swain (in Bagaric \& Djigunovic, 2007) categorized three kinds of language mastery, they are: competence or mastery in implementing grammatical concepts, competence or mastery in application of language in social context in matching the communicative functions, and competencies or mastery in combining what is being pronounced with communicative functions in the discourse principle. In conclusion, their framework is classified into how a speaker is competent in using his or her knowledge in real communication.

Moreover, Hymes (in Bagaric, 2010) classified competence in communication into two categories: competence of linguistic and competence of pragmatic. Competence of linguistic is the capability to implement language in the primary aspects of language that is grammatically, syntactically, and morphology. Meantime, competence of pragmatic is the capability to apply language in context. In addition, in accordance to Leech (in Jabber \& Jinquan, 2013), pragmatics is a language in its implementation, or in other term, language learning in the speaker's meaning. Then, pragmatics is also defined as the correlation among the code of the speaker and the listener. Or in simply words, pragmatics is how language is implemented in the way of communication.

Furthermore, the conservative pragmatist, Levinson (in Saeidi et al, 2014) explained that pragmatics is a study of language implementation. Meanwhile, Kasper and Rose (in Saeidi et al, 2014) emphasized that pragmatics is a discussion of the implementation of communication in a socio-cultural context. Thus, pragmatic studies are closely correspondent with speech acts in a social context. The capability in understanding and using speech acts is recognized as pragmatic competence bearing with cultural schemata and linguistic knowledge as well as social relationship between the two people: speaker and listener.

\subsection{Contextual Materials}

According to Majid (2006: 173) teaching materials are all forms of materials used to help the lecturer in applying the teaching and learning process. Materials are information, tools, and texts that are needed by lecturer in planning and reviewing the implementation of learning process. Some examples of teaching materials are lesson module and dictate. Module is printed teaching materials designed to be studied independently by students. Module is also known as media for independent learning in case it has instructions for learning process (Darma, 2007: 3).

Moreover, in implementing effective teaching learning process, the materials used by the teacher must be contextual;. According to Indonesian Big Dictionary (Ministry of Education, 2010: 751) contextual is interpreted as something related to the context. By its definition, it can be concluded that the contextual material is a field that corresponds with to the place where the learners live, both the natural, artificial, and built environment. In this case, the contextual area is the hotel area where students are studying and working.

\section{METHOD}

\subsection{Participants}

The study was conducted to 40 students of Sekolah Tinggi Ilmu Manajemen Sukma (STIM Sukma), who are studying hotel and tourism management. Students' age range is 19 to 21 years old. Random sampling technique was adopted to choose the students as sample.

\subsection{Research Instrument}

The research is applied based on survey study. According to Yusuf (2014), survey is a way to collect the data from numbers of individual by using questionnaire, interview, or other media. The researcher collected the data from the students by a survey. The questionnaire was established by the researcher and then being validated by expert. Yet, the questionnaire also has been tested. The questions being surveyed were totally about the book, both internally and externally. The respondents were asked about their opinions about the book objectively. The respondents were asked to fill number 1 until 5 about their opinions, where 1 is the lowest (which means very bad) and 5 is the highest (which means very good). 
Moreover, Google Form Application was used as the tools to collect the data. The questionnaire was distributed by online way. The questionnaire link was shared to the students through WhatsUp mobile phone application and also through email. In simple way, the research was carried out by following these steps: 1) collecting the students on a classroom, 2) explaining and teaching the students with pragmatic based materials, then 3) asking them to fulfill the questionnaires. As additional information, the questionnaires are totally related to the book: its use, its function, and its materials' suitability.

\section{RESULTS AND DISCUSSION}

40 respondents were involved to fill up the survey. They were asked about their opinions about the book. The results are shown as follow.

Table.1. Respondents perspective

\begin{tabular}{lll}
\hline $\begin{array}{c}\text { Part of } \\
\text { Judgment }\end{array}$ & \multicolumn{1}{c}{ Criteria } & \multicolumn{1}{c}{$\begin{array}{c}\text { Score } \\
\text { Average }\end{array}$} \\
\hline External & Involving students' lives & 4.45 \\
\hline & Proficiency level & 4.30 \\
\hline & Contextual materials & 4.775 \\
\hline & Appropriate to curriculum & 4.675 \\
\hline & Integrating language, learning process, and & 4.75 \\
& learners & 4.65 \\
\hline Internal & Skill presentation in materials & 4.70 \\
\hline & Integrated skills & 4.25 \\
\hline & $\begin{array}{l}\text { Relationship of tests and exercises to } \\
\text { learners needs and what is taught }\end{array}$ & 4.45 \\
\hline & Suitable for different learning style & 4.75 \\
\hline & $\begin{array}{l}\text { Motivating both students and } \\
\text { teachers }\end{array}$ & 4.80 \\
\hline Overall & Usability (based on curriculum) & 4.30 \\
\hline & $\begin{array}{l}\text { Adaptability (modified for real } \\
\text { circumstance) }\end{array}$ \\
\hline & & \\
\hline
\end{tabular}

\section{Does the book involving your life?}

The question was asked to students about their opinion, whether the materials on the book represent their daily life as the students of hotel management. 29 students or 72.5 percent of respondents very agree that the book represent their lives on hotel management context. The examples on materials bring their daily habituation in facing the guests and staffs in communication. Meanwhile, there were 11 students or $27.5 \%$ stated their agreements about the representativeness of the book with their daily habituation.

\section{How is the proficiency level?}

The question was asked to students about their opinion, whether the materials on the book represent their daily life as the students of hotel management in term of its proficiency level. The books carry practical level certainly, in case the book stimulates students to have direct and contextual practice. The point in level of proficiency is 4.30 , where 24 or $60 \%$ of respondents give score 5 .

Is the material contextual to your daily work?

The question was asked to students about their opinion, whether the materials on the book contextual with their daily life as the students of hotel management. Contextual means the real situations of the material given with the students need after they graduate. The materials according to the respondents are contextual, where 4.775 score is achieved. 31 respondents or $77.5 \%$ percents of them agree that the materials are contextual where they give 5 score.

Is the material appropriate to curriculum?

Curriculum in this term means the unity of the lesson plan and goal in whole education year. The questions was asked to students about their opinion, whether the materials on the book suitable with the curriculum given to them as the students of hotel management. The score achieved is 
4.675. Almost of the respondents agree that the lesson is suitable with the curriculum. Curriculum in respondents' perspective is the suitability of the goal and the lesson they received during the process. 30 of 40 respondents or $75 \%$ said that the book is appropriate to curriculum.

Does the material integrate the language, learning process, and learners?

The question is related with the language being carried on learning process, whether it is integrated with learners' needs or not. The question was asked to students about their opinion, whether the materials on the book integrated all those aspects. $75 \%$ percents of respondents or 30 people say so. The score average achieved is high, 4.75 , which means it really represents what they need in implementing the language later.

Is your skill represented in material?

The materials are developed based on what students will bring on their daily life; include their applied skills in hotel practice. The materials are brought into the students' daily reality life. It is proven based on the fact that 28 among 40 students give score 5 in this aspect. In majority, the students agree that their work environments implementations are represented in materials.

Are all the hotel management skills integrated?

The question was asked to students about their opinion, whether the materials on the book integrate all their hotel management skills on all lessons. The book was created systematical and chronological orders. All the chapters were created in sequence and carry all hotel management skills, started by receptionist matter, telephoning, room supplies, restaurant \& bar, organizational operation, mapping, cultural awareness, and airport matters. It is proven based on the survey result that this point achieve 4.70 where 28 respondents or $70 \%$ give score 5 .

Are the tests and exercises in the book related with your needs?

The question was asked to students about their opinion, whether the test and exercises related to the topic on the chapter on the book related with what have been taught to them. Some students (22) or $55 \%$ students give score 5 which means they think that the exercises given are suitable with have been taught. Meanwhile the rest were giving 4 and 3 points.

Do you think the lesson is suitable to be learnt by different learning style?

The question might be bias and inappropriate to be asked to the respondents, in case that they do not understand about teaching-learning matters. The researcher explained to them what should be answer. They have to assume whether the materials is suitable to be learn with game, group project, or focus group discussion learning style instead of by conservative way (lecturing). In result, this matter gets average 4.45 point. Not too bad.

Are you motivated to study by this book?

This question might be the most important question. The students were asked whether they are motivated to study by this subject or not. According to them, they are motivated to study. It is proven based on the fact that 30 respondents or $75 \%$ percents give score 5 . Meanwhile the rest give score 4. The total score is 4.75 .

How do you think about the usability of the book?

The question was asked to students about their opinion, whether the books is usable for them to be learnt presently and in the future. The question is related with their daily study life and their future life. As they are going to be professional hotelier, they have to have a handed book that will be very useful for them. 4.80 point is achieved in this matter. This is the highest point among all questions. The students felt that the book is very usable for them.

\section{Are you able to adapt with the materials?}

The question was asked to students about their opinion, whether they are able to adapt with the materials on the book. Related to the question previously (k), almost all the respondents stated that they are able to adapt, where 27 of them or $67.5 \%$ of them give 5 points. 


\section{CONCLUSUION}

To mastery pragmatic is very important. It is the knowledge that will be useful to understand others in every communication, especially for students who are involved in the field of hotel and tourism management. The research being conducted is a small research. Other future research is definitely needed to develop other inquiry related to the book being written.

\section{REFERENCES}

BagaricJie, Fang. 2010. A Study on Pragmatic Failure in Cross-Cultural Communication. Sino-US English Teaching. Vol 7. No.12 (p. 42-46)

Darma, Budi. 2007. Bahasa, Sastradan Budi Darma. Surabaya : JP Books.

Indonesia Department of Education. 2010. Kamus Besar Bahasa Indonesia. Jakarta: : Depdiknas.

Jabber, K.W \& Jinquan, Zhang. 2013. The Modal Verbs: A Speech Act of Request in the Speech of the President of the United States Barak Obama. The Criterion Journal. Issue 12 (p. 1-13)

Majid, Abdul. 2006. Perencanaan Pembelajaran. Bandung: PT Remaja Rosdakarya.

Rahman, BI. 2018.Developing English Pragmatic Based Materials for Students of Hotel Management Study Program. SalTel Journal. Vol. I Number 1 (p.28-37)

Santoso, Anang. 2007. Ilmu Bahasa dalam Perspektif Kajian Budaya. Jurnal Bahasa, Sastra, Seni dan Pengajarannya. Vol. 35. Issue 1 (p.1-15)

Saeidi, N.S. 2014. Pragmatic Transfer in Iranian EFL Learners as Compared to Native English Speakers in Realization of the Speech Act Promising. International Journal of Educational Investigation. Vol I Issue 1 (p. 252-267)

Yusuf, A.M. 2014. Metode Penelitian Kualitatlif, Kuantitatif, dan Penelitian Gabungan ( $1^{\text {st }}$ Edition). Jakarta: Kencana 